International Journal of Management Technology

Vol.7, No 1, pp. 1-19, January 2020

Published by ECRTD-UK

Print ISSN: ISSN 2055-0847(Print), Online ISSN: ISSN 2055-0855(Online)

\title{
MEASURING THE AVAILABILITY OF MP S ACCOUNTABILITY AND INTERACTIVITY ON ARAB PARLIAMENTARY WEBSITES USING CONTENT ANALYSIS
}

\author{
Majdi Soubhi Arrif*
}

\begin{abstract}
This study aimed to measure the availability of MPs' accountability and interactivity on Arab PWs, and using the agency-theory as an analytical framework for the resulted findings. A content analysis was conducted at a single point in time during August 2019 to answer the two questions of this study. The final findings were as follows: Bahrain is the best and only Arab country that merely exceeded the (0.5) threshold regarding MPs' accountability and interactivity on its PW. All Arab PWs still lag in deploying digital technologies for citizen engagement, as they do not provide the complete and necessary information to make their MPs accountable and the effective conduits to enhance their MPs' interactivity with citizens. Thus, we can conclude that the aim of building these websites is basically concerned with the web presence, in addition to the provision of some documents and bills. Depending on the "agency-theory", these findings reflect a situation of "hidden actions" which lead to the "moral hazard" problem.
\end{abstract}

KEYWORDS: ICT; parliamentary website; accountability; interactivity; agency-theory; content analysis.

\section{INTRODUCTION}

Nowadays, the environment in which parliaments operate has become more complex and stressful than ever before, especially with the advent of the new technologies and the political mentality change for the public. The challenge is to keep up with the public by displaying responsiveness and resilience and continually renew the relationship with citizens (Power, 2012). ICTs are seen as a means of re-engaging or re-connecting the electorate with their representative and improving the health of modern democracies (Francoli, 2008; Zaharudin, 2014), and considered to be as a way to mitigate the issue of low trust and negative image of legislative institutions (Leston-Bandeira, 2012; Walker, 2012; De Barros, Bernardes and Rehbein, 2016).

Based on these objective realities, Parliaments are adopting digital technologies in performing their legislative activities and in connecting with citizens (Norton 2007; Griffith and Leston-Bandeira 2012; Joshi and Rosenfield 2013; Bravo and Del Valle 2017; Odeyemi and Abioro, 2019). One of these is the internet, which many studies indicated

* Assistant professor of information and decision support systems at Al-Wataniya Private University, Hama, Syria. Nonresident scholar and co-founder of the European Center for Economic Studies of Arab Orient (ECESAO). 
International Journal of Management Technology

Vol.7, No 1, pp. 1-19, January 2020

Published by ECRTD-UK

Print ISSN: ISSN 2055-0847(Print), Online ISSN: ISSN 2055-0855(Online)

that its interactive nature can play a facilitatory role between representatives and citizens (Kingham, 2003; Leston-Bandeira, 2009; Tyumre, 2012). And the other is the parliamentary websites (PWs), which hold particular promise for informing citizens about their national legislature (Joshi and Rosenfield, 2013).

Legislative websites are used to communicate with citizens (Griffith, 2006), by providing detailed information on the acts of parliamentarians (Setälä, and Grönlund, 2006), and provision of contact information and other links by which citizens can communicate their views to MPs (Joshi and Rosenfield, 2013). Legislative websites can facilitate citizens in getting information on specific issues, participating in decision-making processes and convey their acceptance or disagreement on different issues (Ahmed, 2008). But, simply, having a website is not proof of a will to be transparent (Coleman, 2006).

Parliament is itself a barrier to engagement with the public because of arcane traditions and the complexity of its processes and procedures (Williamson et al. 2011; Odeyemi and Abioro, 2019), and this leads to the term: 'unpopularity of parliaments' (Power, 2012; De Barros, Bernardes and Rehbein, 2016). Parliaments in most developing countries tend to be closed institutions (Ahmed, 2008). Arab countries are one of them surely, where citizens were used to vote for parliament nominees and to help them to be the parliament members without a legal accountability or without questioning them what they are intending to do when they win, but they confine themselves just by looking and reading their own agenda regarding their election campaign (Soultanian, 2013).

However, the latest events, which have been occurring in the Arab countries since 2011 reinforce their parliaments to open up and change their conventional ways of interacting with citizens. But, as Ali Sawi stated: "no single Arab parliament [had] succeeded in raising hope among the Arab public as the [primary] source of governing authority or as a key player in the domestic political arena" (Power, 2012). This study, therefore, seeks to contribute in promoting democracy and citizen engagement by measuring the availability of MPs' accountability and interactivity on Arab PWs, and using the agency-theory as an analytical framework for the resulted findings.

\section{Parliamentary accountability}

Accountability is a two-sided concept in the parliamentary arena. The first side refers to questioning the executives by parliamentarians as agents of citizens. While the second refers to the ability of citizens to make the parliamentarians' themselves accountable to them, and that is the focus of this study. Generally, an agent is accountable to his principal if (1) he is obliged to act on the latter's behalf, and (2) the latter is empowered to reward or punish him for his performance in this capacity. Note that political agents may be individual or collective, as may principals (Strom, 2000).

One of the most distinct features of representative democracies is that those who govern can be held accountable (Grant and Keohane 2005; Sprungk, 2010), and principals have the capabilities to pass judgment on the performance of their agents (Lupia, McCubbins 
International Journal of Management Technology

Vol.7, No 1, pp. 1-19, January 2020

Published by ECRTD-UK

Print ISSN: ISSN 2055-0847(Print), Online ISSN: ISSN 2055-0855(Online)

and Arthur 1998; Achen and Bartels 2002; Healy and Malhotra 2010; Lenz 2012; Gailmard, 2012; Asamoah, 2018).

Democratic constitutions contain mechanisms that allow principals to delegate (Strom, 2000) and at the same time, give them the right to demand information to agents and a capacity to impose sanctions (DE DIOS, 2014)Holding someone accountable usually means punishing an unwanted prior behavior (Karlsson, 2013). This could be applied by using the electoral mechanism to shape the incentives facing politicians. In such models, politicians perform well because they fear being turned out of office if they do not (Humphreys and Weinstein, 2012).

If parliaments have the will to be transparent, then they should declare all the activities of their MPs (e. g. legislative proposals, questions, participation and voting record etc.). Thus, citizens will have the ability to hold them accountable.

\section{Parliamentary interactivity}

Interactivity in political representation is here defined as the practice among political representatives of interacting in a responsive fashion with their voters, constituents, or citizens, generally regarding topics related to the relationship of representation (Karlsson, 2013). In such communication, communicators work together to ask questions, find answers, and formulate policies and actions (Serra-Silva, 2016).

Parliaments must adopt communicative strategies which allow citizens to see in and scrutinize and parliaments to see out and learn from public discussion (coleman, 2006).

Social media, using Web 2.0 technology, has emerged over the past few years as growing space for online communication (Missingham, 2011). Web 2.0 technologies are facilitating new interactivity features (Serra-Silva, 2016), and considered to be ones which enable two-way communication, such as: blogs, wikis, twitter, and Facebook. For instance, MPs can use personal blogs to inform the public and key stakeholders their positions on various policies or policy issues (Manda and Hilika, 2016). This means that blogging, sharing of ideas is at the kernel of any well-functioning society (Suomi, 2008).

PWs can host online discussion groups, forums, surveys, public hearings, blogs, polls, epetitions and chats for soliciting citizens' opinions (Berntzen et al., 2006; Joshi and Rosenfield, 2013; Sobaci, 2010). The higher levels of interactivity result in more positive evaluation of the website and the content that is presented (Serra-Silva, 2016).

\section{Agency-theory}

Principal-agent theory has become a widely used paradigm for analyzing public accountability (Gailmard, 2012). Agency-theory, which describes situations in which one party (an agent) acts on behalf of another (the principal) (Kiewiet and McCubbins 1991; Aghion and Tirole 1997; Lupia and McCubbins 2000), tells us that delegation takes place because the agent has certain kinds of information or skills (e.g., in the form of professional training), or simply time, that the principal lacks. The reason that we do not make all 
International Journal of Management Technology

Vol.7, No 1, pp. 1-19, January 2020

Published by ECRTD-UK

Print ISSN: ISSN 2055-0847(Print), Online ISSN: ISSN 2055-0855(Online)

political decisions through direct democracy is for one thing that we simply do not have the time, and secondly that we do not trust our ability to make well-informed and mutually consistent decisions (Strom, 2000).

Agency process is based on delegation and accountability (DE DIOS, 2014). Voters delegate to parliamentarians, who in turn delegate to members of the cabinet. Similarly, accountability is indirect, in that cabinet members are accountable to members of parliament, who in turn answer to the voters (Strom, 2000). Many constitutions explicitly designate parliamentarians as representatives of all citizens, and not simply of those that elected them or to whom they are accountable (Strom, 2000).

Agency problems are likely to be exacerbated under hidden information (principals do not fully know the competencies or preferences of their agents or the exact demands of the task at hand) or hidden action (principals cannot fully observe the actions of their agents) (Strom, 2000), and we can add (principals cannot fully observe the moonlighting activities of their agents) (Geys and Mause, 2012). The former of these conditions can give rise to problems of adverse selection, the latter to moral hazard (Strom, 2000; Sprungk, 2010). The former of these problems may lead principals to systemically select "the wrong" agents, agents that do not have the most appropriate skills or preferences. The problem of moral hazard, on the other hand, arises when agents, once selected, have incentives and opportunity to take unobservable action that is contrary to the interests of the principal (Strom, 2000; Lupia, 2003; Sprungk, 2010; DE DIOS, 2014), and the principal cannot directly control the agent's action (Gailmard, 2012; Asamoah, 2018).

There are four institutional mechanisms that permit principals to control their agents. One is the contract design, another is screening and selecting mechanisms of agents the, third is monitoring and reporting requirements, and the four institutional checks (Kiewiet and McCubbins 1991; Strom, 2000; DE DIOS, 2014). The former two are ex ante mechanisms for containing agency losses and permit the principal to learn about his agent before she acts and look for the best agent. The other two are ex post mechanisms of control that permits the principals to learn about agent's action after the fact (Strom, 2000; DE DIOS, 2014).

\section{LITERATURE REVIEW}

We will briefly review the existing literature on PWs analysis by pointing to its theoretical shortcomings. The study of (Setälä, and Grönlund, 2006) analyzed the contents of the parliamentary websites in 18 democratic countries (including Canada, USA, Australia, and countries in the EU). Results showed the similarity of the contents of parliamentary websites in the 18 established democracies. Apart from the information on individual representatives' voting behavior which can be found only on nine websites, all parliamentary websites indeed provide citizens with a lot of information needed for ex post scrutiny. The increased publicity of parliamentary plenary debates can be considered valuable. Parliamentary websites do not, however, increase the scope of matters that are 
International Journal of Management Technology

Vol.7, No 1, pp. 1-19, January 2020

Published by ECRTD-UK

Print ISSN: ISSN 2055-0847(Print), Online ISSN: ISSN 2055-0855(Online)

public. Websites increase people's direct access to parliamentary information and also communication between voters and the representatives.

While the study of (Coleman, 2006) conducted an analysis for 44 European PWs, which aimed to consider how far digital ICT are being used to make parliaments more open/transparent and discursive/consultative. Concluded that there is limited use of interactive features which allow citizens to comment and deliberate on policy.Also, (Leston-Bandeira, 2009) used data from a pilot study on the websites of 15 parliaments in the EU to identify which parliamentary functions are portrayed on these websites. Results showed that Legislation is by far the main priority of parliamentary websites in Europe, despite the fact that there is considerable literature showing that parliaments' effective role in legislation is in fact very weak. Often there is not a match between what parliaments do - their role - and what their websites show.

From the other hand (Joshi and Rosenfield, 2013) conducted seminal empirical examination of all 184 functioning lower house and unicameral PWs around the world, by focusing on transparency, and communication links and social media. The study found that although PWs in wealthy democracies generally provide more MP information, the majority of PWs are deficient in providing basic MP information to citizens and utilizing linkages to social media. By contrast, some nondemocratic states and newly democratized countries, especially those with compulsory voting, display a relatively high level of MP transparency and social media connectivity.

While the study of (Hamajoda, 2016) aimed to evaluate ECOWAS members' websites based on a modified version of the guidelines recommended by Inter-Parliamentary Union (IPU) in 2009. Concluded that while most Member States websites score well on general information about their parliaments, they lacked progress in making their websites a onestop point for political information about their countries, and a fulcrum for interaction between legislators and citizens and a real time deliberation on burning national and regional issues despite the current availability of suitable interactive tools on the internet. The study of (De Barros, Bernardes and Rehbein, 2016) examined how new technologies (public digital hearings, e-Democracy, parliamentary website, chamber TV and social media) are employed by the Brazilian Chamber of Deputies to stimulate experiences of digital engagement. The study concluded that the use of digital technologies by the Brazilian Parliament is very diverse, with a variety of tools that allow for the interaction and engagement of citizens, although these tools have the greatest potential for the arena parliament model.

The study of (Oni, Oni and Ibietan, 2016) aimed to analyze the parliamentary websites of 17 democratic states of Africa (including Morocco) for information content and interactive tools. Concluded that despite such challenges as inadequate infrastructural facilities and capacity building in most African States, the exponential growth of ICTs in the continent, has the potential for strengthening interactive deliberation between citizens and their 
International Journal of Management Technology

Vol.7, No 1, pp. 1-19, January 2020

Published by ECRTD-UK

Print ISSN: ISSN 2055-0847(Print), Online ISSN: ISSN 2055-0855(Online)

representatives and thus reduce citizens- representatives' estrangement and make democratic processes more inclusive and transparent.

Furthermore, the study of (Bernardes and Bandeira 2016) developed a comparative analysis of the websites of the lower chambers of the Brazilian and the British parliaments based on three dimensions: information about the institution, information about the parliamentary activity carried out by members and Tools aimed at promoting interaction between public and legislature. The analysis showed that both websites achieve much higher levels of complexity in the information area than in engagement. But it also showed that the Brazilian parliament website includes far more tools designed for public interaction than its UK counterpart.

Following the method of (Bernardes and Bandeira 2016), the study of (Odeyemi and Abioro, 2019) conducted an analysis of the websites of Nigeria's Senate and House of Representatives as well as South Africa's National Assembly and National Council of Provinces through focusing on issues relating to the information about the parliaments, information on parliamentarians and citizen engagement. The study concluded with, in the Nigerian case, beyond websites, social media platforms continue to record expanding levels of use by citizens and have now become means of facilitating deeper levels of statesociety relations that are critical to inclusive governance. The parliament of South Africa demonstrates the high e-government ranking with the volume of information and tools made available for public engagement, including institutional email addresses for all MPs. However, there are prospects of significant improvements by aligning social media platforms of individual MPs with their pages on the parliamentary website to facilitate engagement with constituents.

None of the above studies mentioned anything regarding Arab PWs analysis except the study of (Joshi and Rosenfield, 2013), which analyzed half of this study's websites focusing on two dimensions. First: transparency, which contains MPs' background information, while this study expands the transparency into accountability by adding items related to information on MPs' activities. Second: communication links and social media, whereas this study focuses on interactivity in general, which includes other communication channels in addition to the contact information and social media links applied by the study of Joshi and Rosenfield. And the study of (Oni, Oni and Ibietan, 2016) which only analyzed the website of Morocco by focusing on the items: information content, and interactive tools.

We can say therefore, that there is a theoretical gap in this field and this study seeks to fill it. This study gains its originality from being the first and only work to analyze all Arab PWs depending on two dimensions: MP's accountability and interactivity, and using the agency-theory as an analytical framework for the resulted findings. Although, this study is a sequence to our first one (Arrif, 2018), which conducted an analysis for only eight Arab PWs by focusing on the accountability and interactivity of the parliament itself more than 
PMs in addition to transparency, usability and accessibility. But this study differs by focusing only on MP's accountability and interactivity.

\section{Questions}

Literatures had pointed out that the main objective of designing PWs is to remove barriers between parliaments and the public. We can say, by the same token, that the objectives of launching PWs tend to fall into two categories: first, the provision of documents and bills with the stakeholders. Second, the provision of information related to accountability that reflects MPs performance and achieving of their electoral promises (manifesto), in addition to sharing of contact information that allow the public to interact with MPs and share their opinions with them. From the researcher's point of view, the latter category is more important than the former ones. Reasoning this preference lies in the fact that parliamentary documents and idioms are often incomprehensible to the public, and many of which require significant amounts of knowledge and understanding not possessed by most of the public (Williamson et al. 2011; Odeyemi and Abioro, 2019). Whereas contacting with MPs and delivering complains to them is more important to the public. This corresponds to (Kelso, 2007) metaphor which states that: "public aren't interested in how the engine works, but what the car can do in terms of performance". Thus, we can ask the two following questions:

* Do Arab PWs declare the information related to MPs' performance, which allow MPs' accountability by the public?

* Do Arab PWs consider the interactivity between MPs and the public, by sharing the necessary contact information with them?

\section{Sample and methodology}

In order to identify the sample of this study, the Google search engine was used to conduct a search of three phases:

First: access League of Arab States website to limit all member countries, which numbered 22 countries. South Sudan, which gained independence in 2011 has not yet joined the League because English is the official language. However, South Sudan does not have an official PW.

Second: access the PARLINE database on national parliaments to identify the type, name and URL of each Arab PW. It turns out that Qatar does not have an official PW, while the Palestinian parliament is not defined in the PARLINE database. Investigating the reason behind the latter being not defined, showed that there are two PWs: the first is for West Bank government, while the second is for Gaza Strip government. This situation reflects the division that has taken place there since 2007, which in turn led the IPU to exclude the Palestinian parliament from its PARLINE database, and we do so by excluding it from this study. 
International Journal of Management Technology

Vol.7, No 1, pp. 1-19, January 2020

Published by ECRTD-UK

Print ISSN: ISSN 2055-0847(Print), Online ISSN: ISSN 2055-0855(Online)

Third: check out the validity of each URL. The URL of Libyan PW was replaced by the end of 2018 to be (http://parliament.ly/) instead of (http://www.libyan-parliament.org/). The URLs of Sudan and Comoros were invalid at the time of this study preparation, but were accessed using the web.archive.org website. Last snapshot was on 16/04/2019 and $13 / 03 / 2016$ for each, respectively. Given the long time that has elapsed since the last update of the Comoros website, this led us to exclude it from this study.

Therefore, the final sample contains 19 countries. (Table 1) illustrates the type, name and URLs of the analyzed Arab PWs.

Table 1: Type, Name, and URLs of the Analyzed Arab PWs

\begin{tabular}{|c|c|c|c|}
\hline Country & $\begin{array}{l}\text { Legislature's } \\
\text { type }\end{array}$ & Legislature's name & Legislature's URL \\
\hline UAE & Unicameral & Majlis Watani Itihadi / Federal National Council & http://www.almajles.gov.ae/ \\
\hline KSA & Unicameral & Majlis Ash-Shura / Shura Council & http://www.shura.gov.sa/ \\
\hline Kuwait & Unicameral & Majles Al-Ommah / National Assembly & http://www.kna.kw/ \\
\hline Bahrain & Bicameral & Majlis Al-Nuwab / Council of Representatives & http://www.nuwab.bh/ \\
\hline Oman & Bicameral & Majles A'Shura / Consultative Council & http://www.shura.om/ \\
\hline Lebanon & Unicameral & Majlis Al-Nuwwab / National Assembly & https://www.lp.gov.lb/ \\
\hline Tunisia & Unicameral & $\begin{array}{l}\text { Majlis Nawwab ash-Sha'ab / Assembly of People's } \\
\text { Representatives }\end{array}$ & http://www.arp.tn/ \\
\hline Jordan & Bicameral & Majlis Al-Nuwaab / House of Representatives & http://www.representatives.jo/ \\
\hline Morocco & Bicameral & Majliss-annouwab / House of Representatives & $\begin{array}{l}\text { http://www.chambredesrepresent } \\
\text { ants.ma/ }\end{array}$ \\
\hline Algeria & Bicameral & $\begin{array}{l}\text { Al-Majlis Al-Chaabi } \\
\text { People's Assembly }\end{array}$ & http://www.apn.dz/ \\
\hline Djibouti & Unicameral & Assemblée nationale / National Assembly & $\begin{array}{l}\text { http://www.assemblee- } \\
\text { nationale.dj/ }\end{array}$ \\
\hline Syria & Unicameral & Majlis Al-Chaab / People's Assembly & http://www.parliament.gov.sy \\
\hline Somalia & Bicameral & House of the People & http://www.parliament.gov.so \\
\hline Iraq & Unicameral & Council of Representatives of Iraq & http://www.parliament.iq/ \\
\hline Libya & Unicameral & Majlis Al-Nuwaab / House of Representatives & $\begin{array}{l}\text { http://www.libyan- } \\
\text { parliament.org/ }\end{array}$ \\
\hline Egypt & Unicameral & Majlis Al-Nuwaab / House of Representatives & http://www.parliament.gov.eg/ \\
\hline Mauritania & Unicameral & Al Jamiya-Al-Wataniya / National Assembly & $\begin{array}{l}\text { http://www.assembleenationale. } \\
\mathrm{mr} /\end{array}$ \\
\hline Yemen & Bicameral & Majlis Annowab / House of Representatives & http://yemenparliament.gov.ye/ \\
\hline Sudan & Bicameral & Majlis Watani / National Assembly & http://www.parliament.gov.sd/ \\
\hline
\end{tabular}

Source: PARLINE database on national parliaments.

The content analysis was conducted at a single point in time during August 2019. Following our study (Arrif, 2018), all websites of unicameral legislatures and lower chambers of bicameral parliaments were analyzed using a dichotomous coding scheme. For the scaling process, this study calculates the proportions of each country by each of the two dimensions, noticing that the proportion of $(0.5)$ means a middle quality of services. 
International Journal of Management Technology

Vol.7, No 1, pp. 1-19, January 2020

Published by ECRTD-UK

Print ISSN: ISSN 2055-0847(Print), Online ISSN: ISSN 2055-0855(Online)

The PWs of both of Djibouti and Somalia are monolingual. French is the formal language for the first one, while Somali is for the second, and Arabic or English are not available. Therefore, the process of coding those two websites was conducted with the aim of Google translation software.

\section{Analysis}

The aim of this analysis is to answer the two questions related to the two dimensions: MP's accountability and interactivity. The items included here are derived from the most relevant works and numbered 20 and 10 for each dimension, respectively.

\section{MPs' accountability}

We can notice from (Table 2) that only 8 out of 19 countries about (42\%) are above (0.5) threshold. Bahrain has the highest proportion of (0.65), followed by UAE and Kuwait with (0.6), and Lebanon merely exceeded the threshold with a proportion of (0.55), while Iraq, Syria, Jordan and Morocco reached the threshold, exactly. To gain further insight, we will analyze the items of this dimension:

Table 2: Proportions of Accountability Dimension

\begin{tabular}{|c|c|c|c|c|c|c|c|c|c|c|c|c|c|c|c|c|c|c|}
\hline Items $\backslash$ Countries & $E$ & 8 & . & & & & & & & & & & & & 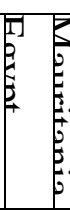 & . & & \\
\hline \multicolumn{19}{|c|}{ Information on members of parliament } \\
\hline $\begin{array}{l}\text { List of past presiding officers } 1 \text {, } \\
2,3\end{array}$ & 1 & 0 & 1 & 1 & 0 & 1 & 0 & 1 & 0 & 1 & 0 & 0 & $0 \mid 0$ & 0 & 1 & 0 & 1 & 1 \\
\hline $\begin{array}{l}\text { Bio data of presiding officers } 1 \text {, } \\
2,3\end{array}$ & 1 & 1 & 1 & 1 & 1 & 1 & 1 & 1 & 1 & 0 & 0 & 10 & $0 \mid 1$ & 0 & 1 & 0 & 1 & 1 \\
\hline $\begin{array}{lll}\begin{array}{l}\text { Presiding } \\
\text { agendas } 3\end{array} & \text { officers' } & \text { public } \\
& & \end{array}$ & 0 & 0 & 0 & 0 & 0 & 0 & 0 & 0 & 0 & 0 & 0 & 0 & $0 \mid 0$ & 0 & 0 & 0 & 0 & 0 \\
\hline Important speeches 3 & 1 & 0 & 1 & 1 & 1 & 1 & 1 & 1 & 1 & 1 & 0 & 10 & \begin{tabular}{l|l}
0 & 1
\end{tabular} & 0 & 1 & 1 & 0 & 0 \\
\hline $\begin{array}{l}\text { List of previous members } 1,2,3 \text {, } \\
5\end{array}$ & 1 & 0 & 0 & 1 & 1 & 1 & 1 & 1 & 1 & 1 & 1 & 11 & $1 \mid 0$ & 0 & 0 & 0 & 0 & 0 \\
\hline $\begin{array}{l}\text { Bio data of previous members } 1 \text {, } \\
2,5\end{array}$ & 0 & 0 & 0 & 0 & 0 & 0 & 1 & 0 & 0 & 0 & 0 & 10 & $0 \mid 0$ & 0 & 0 & 0 & 0 & 0 \\
\hline $\begin{array}{l}\text { Up-to-date list of all current } \\
\text { members } 1,2,3,4,5,6,7,8\end{array}$ & 1 & 1 & 1 & 1 & 1 & 1 & 1 & 1 & 1 & 1 & 1 & 11 & $1 \mid 1$ & 1 & 1 & 1 & 1 & 0 \\
\hline $\begin{array}{l}\text { Bio data of all current members } \\
1,2,3,4,5,6,7,8,9\end{array}$ & 1 & 1 & 1 & 1 & 1 & 1 & 1 & 0 & 0 & 0 & 0 & 10 & $\begin{array}{lll}0 & 0\end{array}$ & 0 & 0 & 0 & 1 & 0 \\
\hline $\begin{array}{l}\text { Description of representative } \\
\text { duties and functions of members } \\
1,2,5\end{array}$ & 1 & 1 & 1 & 1 & 1 & 1 & 1 & 0 & 0 & 0 & 0 & 11 & $\begin{array}{lll}1 & 1\end{array}$ & 0 & 1 & 0 & 0 & 0 \\
\hline $\begin{array}{l}\text { Information about each } \\
\text { member's constituency, party } \\
\text { affiliation, membership in }\end{array}$ & 1 & 1 & 1 & 1 & 1 & 1 & 1 & 1 & 1 & 1 & 1 & 11 & $\begin{array}{lll}1 & 1\end{array}$ & 0 & 1 & 1 & 1 & 0 \\
\hline
\end{tabular}




\begin{tabular}{|c|c|c|c|c|c|c|c|c|c|c|c|c|c|c|c|c|c|c|c|c|}
\hline $\begin{array}{l}\text { parliamentary committees } \\
\text { and/or commissions } \\
1,2,3,4,5 \text {, } \\
6,8,9\end{array}$ & & & & & & & & & & & & & & & & & & & & \\
\hline $\begin{array}{l}\text { Statistical and demographic data } \\
\text { (current and historical) on } \\
\text { members of parliament (gender, } \\
\text { age, education, job, etc.) } 1,2,5\end{array}$ & 0 & 0 & 0 & & & 0 & 0 & 0 & 0 & 1 & 1 & 0 & 1 & 1 & 0 & 0 & 1 & 0 & 0 & 0 \\
\hline Proportions & $\sqrt{3}$ & & s. & & 2. & & S & $e^{2}$ & 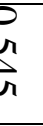 & sing & $\int_{1}^{2}$ & $\int^{2}$ & 6 & $\begin{array}{l}S \\
\lambda \\
n\end{array}$ & $\frac{f}{r}$ & & Sh & , & $f_{i}^{f}$ & p \\
\hline \multicolumn{21}{|c|}{ Information on activities of individual members } \\
\hline Political manifesto 9 & 0 & 0 & ( & & j & 0 & 0 & 0 & 0 & 0 & 0 & 0 & 0 & 0 & 0 & 0 & 0 & 0 & 0 & 0 \\
\hline Legislative proposals 1,2 & 0 & 0 & 1 & & 1 & 0 & 0 & 0 & 1 & 0 & 0 & 0 & 0 & 0 & 0 & 0 & 0 & 0 & 0 & 0 \\
\hline Questions 1, 2, 6 & 1 & 0 & 1 & & 1 & 0 & 0 & 1 & 1 & 1 & 1 & 0 & 0 & 0 & 1 & 0 & 0 & 0 & 1 & 0 \\
\hline Interpellations $1,2,6$ & 0 & 0 & 1 & & 1 & 0 & 0 & 1 & 0 & 0 & 0 & 0 & 0 & 0 & 1 & 0 & 0 & 0 & 0 & 0 \\
\hline Political declarations 1,2 & 0 & 0 & ( & & $\mathrm{J}$ & 0 & 0 & 0 & 0 & 0 & 0 & 0 & 0 & 0 & 0 & 1 & 0 & 0 & 0 & 0 \\
\hline $\begin{array}{l}\text { Participation and voting record } \\
1,2,3,5,7,10\end{array}$ & 1 & 0 & ( & & j & 0 & 0 & 0 & 0 & 0 & 0 & 0 & 0 & 0 & 1 & 0 & 0 & 0 & 0 & 0 \\
\hline Parliamentary immunity 1,5 & 1 & 1 & 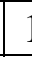 & & 1 & 1 & 1 & 1 & 1 & 1 & 1 & 0 & 1 & 1 & 1 & 0 & 1 & 0 & 0 & 1 \\
\hline Salaries and allowances $1,2,5$ & 0 & 1 & ( & & & 0 & 0 & 0 & 0 & 0 & 0 & 0 & 0 & 0 & 0 & 0 & 0 & 0 & 0 & 0 \\
\hline Moonlighting activities 11 & 1 & 1 & 1 & & & 1 & 1 & 0 & 1 & 0 & 0 & 0 & 0 & 0 & 1 & 0 & 0 & 0 & 0 & 0 \\
\hline Proportions & & & & & & & & & & & & & & P & 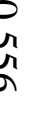 & P & & R & & U \\
\hline Total Proportions & & & & & & & & & & & & & & 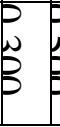 & 5 & & & 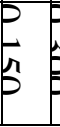 & & $\sigma_{1}$ \\
\hline
\end{tabular}

Sources: 1- (IPU); 2- (Bernardes and Bandeira, 2016); 3- (Hamajoda, 2016); 4- (Sobaci, 2010); 5- (Treschel, et.al, 2003); 6- (Leston-Bandeira, 2009); 7- (Setälä, and Grönlund, 2006); 8- (Joshi and Rosenfield, 2013); 9- (Suomi, 2008); 10- (Coleman, 2006); 11- (Geys and Mause, 2012).

Information on members of parliament: We can notice from (Table 2) that more than half of the sample countries (11 out of 19) about (58\%) are above (0.5). Syria has the highest proportion of $(0.818)$, followed by UAE, Bahrain, Lebanon and Jordan with a proportion of (0.727), while Tunisia, Algeria and Morocco merely exceeded the (0.5) threshold with a proportion of $(0.545)$.

Websites of UAE, Kuwait, Bahrain, Yemen, Jordan, Egypt, Sudan, Algeria and Morocco provide a "list of past presiding officers". All countries share the "bio data of presiding officers" except Libya, Algeria, Mauritania, Djibouti and Somalia. The 19 countries do not share the "presiding officers' public agendas" maybe for safety reasons. All countries present "important speeches" except KSA, Yemen, Sudan, Libya and Djibouti. The 
websites of UAE, Bahrain, Oman, Syria, Lebanon, Tunisia, Algeria, Morocco and Djibouti declare a "list of previous members", but only Syria and Lebanon pay attention to make the "bio data of previous members" available on their websites. Except Sudan, all websites declare "up-to-date list of all current members", but only UAE, KSA, Kuwait, Bahrain, Oman, Yemen, Syria, Lebanon and Jordan share the "bio data of all current members". All websites declare a "description of representative duties and functions of members" except Yemen, Sudan, Libya, Tunisia, Algeria, Morocco, Mauritania and Djibouti. ALL websites share "information about each member's constituency, party affiliation, membership in parliamentary committees and/or commissions" except Sudan and Libya. Only Syria, Egypt, Tunisia, Algeria and Somalia provide "statistical and demographic data (current and historical) on members of parliament (gender, age, education, job, etc.)".

Information on activities of individual members: We can also notice from (Table 2) that only three countries merely exceeded the (0.5) threshold. These countries are Kuwait, Bahrain and Iraq, each of which scored a proportion of (0.556).

MPs' "political manifesto" is not available on all Arab PWs. Only Kuwait, Bahrain and Morocco declare MPs' "legislative proposals". UAE, Kuwait, Bahrain, Yemen, Iraq, Lebanon, Tunisia, Algeria and Morocco declare MPs' "questions". Only Kuwait, Bahrain, Iraq and Lebanon declare MPs' "interpellations". MPs' "political declarations" are not available on all Arab PWs. Only UAE and Iraq share the MPs' "participation and voting record". Except Yemen, Libya, Mauritania and Djibouti, the rest of Arab PWs are keen on illustrating the "parliamentary immunity" of their MPs, but in contrast they all avoid declaring the information related to MPs" "salaries and allowances" except KSA and Bahrain, only. Including moonlighting activities in this study distinguishes it from the rest. It is a very important indicator that reflects the time spent by each parliamentarian to conduct his own business besides his political activities within the parliament, which sometimes leads to conflicts of interests. Only UAE, KSA, Kuwait, Oman, Iraq, Jordan and Morocco declare their MPs' "moonlighting activities". 
International Journal of Management Technology

Vol.7, No 1, pp. 1-19, January 2020

Published by ECRTD-UK

Print ISSN: ISSN 2055-0847(Print), Online ISSN: ISSN 2055-0855(Online)

\section{MPs' interactivity}

We can notice from (Table 3 ) that none of the Arab PWs exceeded the (0.5) threshold, and 7 countries do not provide anything regarding MPs' interactivity with citizens. To gain further insight, we will analyze the items of this dimension:

Table 3: Proportions of Interactivity Dimension

\begin{tabular}{|c|c|c|c|c|c|c|c|c|c|c|c|c|c|c|c|c|c|c|}
\hline Items $\backslash$ Countries & $\vec{B}$ & & & & ק & & & & & & 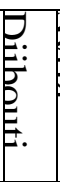 & & & & & 盾 & $\int_{0}^{2}$ & $\frac{5}{2}$ \\
\hline \multicolumn{19}{|c|}{ Multilateral interactivity (two-way communication) } \\
\hline Blogs $1,2,6$ & 0 & 0 & 0 & 0 & 0 & 0 & 0 & 0 & 0 & 0 & 0 & 0 & 0 & 0 & \begin{tabular}{l|l}
0 & $(1$ \\
\end{tabular} & \begin{tabular}{l|l}
0 & 0 \\
\end{tabular} & \begin{tabular}{l|l}
0 & 0
\end{tabular} & 0 \\
\hline $\begin{array}{l}\text { Online fora and discussions } \\
1,2,3,4,5,7,9,11\end{array}$ & 0 & 0 & 0 & 0 & 0 & 0 & 0 & 0 & 0 & 0 & 0 & 0 & 0 & 0 & $0 \mid($ & $0 \mid 0$ & 0 & 0 \\
\hline Chat rooms $2,4,9,12$ & 0 & 0 & 0 & 0 & 0 & 0 & 0 & 0 & 0 & 0 & 0 & 0 & 0 & \begin{tabular}{l|l}
0 & \\
\end{tabular} & \begin{tabular}{l|l}
0 & ( \\
\end{tabular} & \begin{tabular}{l|l}
0 & 0 \\
\end{tabular} & \begin{tabular}{l|l}
0 & 0 \\
\end{tabular} & 0 \\
\hline $\begin{array}{l}\text { Links to social media for } \\
\text { MPs } 2,6,8\end{array}$ & 0 & 0 & 0 & 1 & 1 & 0 & 0 & 0 & 0 & 0 & 0 & 0 & 0 & 0 & 0 & $0 \mid 0$ & 0 & 0 \\
\hline $\begin{array}{l}\text { Comments and questions } \\
\text { for presiding officers } 3\end{array}$ & 0 & 0 & 0 & 0 & 1 & 0 & 1 & 0 & 0 & 0 & 0 & 0 & 0 & 0 & 0 & 0 & 0 & 0 \\
\hline \multicolumn{19}{|c|}{ Bilateral interactivity (one-way communication) } \\
\hline $\begin{array}{l}\text { Contact information for } \\
\text { each member including e- } \\
\text { mail address } 1,2,3,4,5,6 \text {, } \\
7,8,10,11\end{array}$ & 1 & 1 & 0 & 1 & 1 & 0 & 0 & 0 & 0 & 0 & 0 & 0 & 0 & 0 & $0 \mid($ & 0 & 0 & 0 \\
\hline $\begin{array}{l}\text { Alerting services for } \\
\text { members' activities } 1,2,5\end{array}$ & 0 & 0 & 0 & 0 & 0 & 0 & 0 & 0 & 0 & 0 & 0 & 0 & 0 & 0 & $0 \mid($ & $0 \mid 0$ & 0 & 0 \\
\hline $\begin{array}{l}\text { Links to personal website } \\
\text { of each member } 1,2,5,6 \text {, } \\
10,11\end{array}$ & 0 & 0 & 0 & 0 & 0 & 0 & 0 & 0 & 0 & 0 & 0 & 0 & 0 & 0 & 0 & \begin{tabular}{l|l}
0 & 0
\end{tabular} & \begin{tabular}{l|l}
0 & 0
\end{tabular} & 0 \\
\hline $\begin{array}{l}\text { Audio or video broadcast } \\
\text { or webcast of meetings and } \\
\text { plenary } 1,2,3,4,5,6,7,11\end{array}$ & 0 & 0 & 0 & 1 & 0 & 0 & 0 & 1 & 1 & 0 & 0 & 0 & 0 & 0 & 0 & \begin{tabular}{l|l}
0 & 0
\end{tabular} & 0 & 0 \\
\hline $\begin{array}{l}\text { Audio or video archive of } \\
\text { meetings and plenary } 1,2 \text {, } \\
3,4,5,6,7\end{array}$ & 0 & 1 & 1 & 1 & 1 & 1 & 0 & 1 & 1 & 0 & 0 & 0 & 0 & 1 & 0 & $1 \mid 0$ & \begin{tabular}{l|l}
0 & 0
\end{tabular} & 1 \\
\hline Proportions & B & $\square$ & P & & p & P & $\frac{P}{3}$ & $\mathfrak{B}$ & 3 & 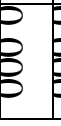 & 3 & 3 & 3 & 3 & 35 & $\frac{3}{3}$ & 3 & P \\
\hline
\end{tabular}

Sources: 1- (IPU); 2- (Bernardes and Bandeira, 2016); 3- (Hamajoda, 2016); 4- (Sobaci, 2010); 5- (Treschel, et.al, 2003); 6- (Leston-Bandeira, 2009); 7- (Setälä and Grönlund, 2006); 8- (Joshi and Rosenfield, 2013); 9- (Parajuli, 2007); 10- (Suomi, 2008); 11(Coleman, 2006).

Multilateral interactivity: We can notice from (Table 3) that none of the Arab PWs provide "blogs, online fora and discussions and chat rooms". Only Bahrain and Oman share "links 
Print ISSN: ISSN 2055-0847(Print), Online ISSN: ISSN 2055-0855(Online)

to social media for MPs", while only Oman and Lebanon make "comments and questions for presiding officers" available on their PWs.

Bilateral interactivity: We can also notice from (Table 3) that none of the Arab PWs share "contact information for each member including e-mail address" except UAE and Oman, which share e-mail address only, while KSA shares only e-mails but not for all members. None of the Arab PWs provide "alerting services for members' activities" and "links to personal website of each member". Only Bahrain provides "audio and video broadcast and webcast of meetings and plenary", while only Tunisia and Morocco provide "video webcast of meetings and plenary". Only KSA, Kuwait, Bahrain, Oman, Iraq, Jordan, Egypt, Sudan, Tunisia and Morocco provide "audio or video archive of meetings and plenary".

\section{Rating Arab PWs}

(Table 4) shows that the total proportions regarding MPs' accountability and interactivity dimensions for all Arab PWs are below the (0.5) threshold except Bahrain, which merely exceeded the threshold with a proportion of (0.525). The same table also illustrates the Arab PWs rating according to each of the two dimensions.

Table 4: Proportions of Total Dimensions

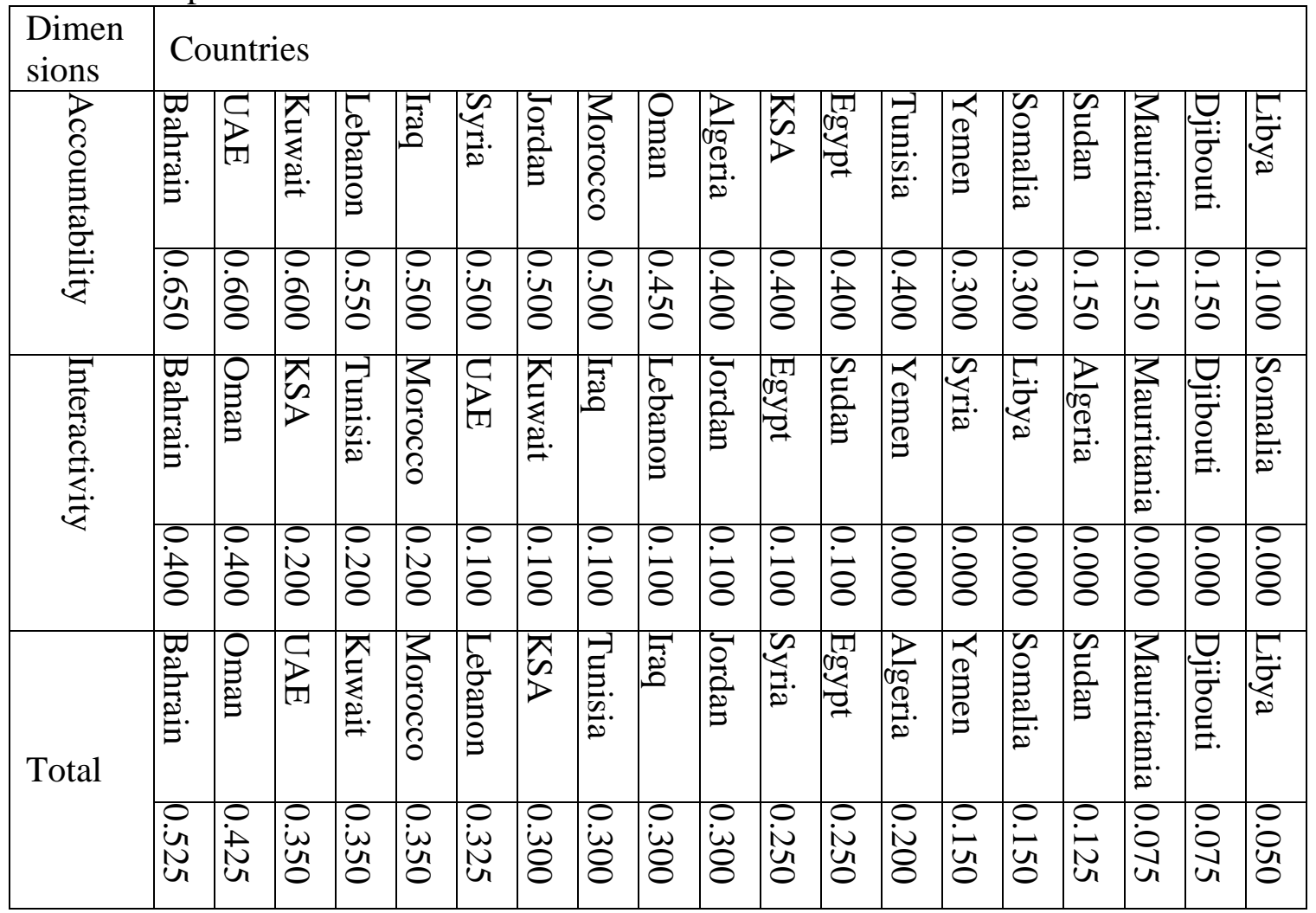

Source: prepared by the author. 
International Journal of Management Technology

Vol.7, No 1, pp. 1-19, January 2020

Published by ECRTD-UK

Print ISSN: ISSN 2055-0847(Print), Online ISSN: ISSN 2055-0855(Online)

\section{FINDINGS}

The following findings came to light from the above analysis:

Bahrain is the best and only Arab country that merely exceeded the (0.5) threshold regarding MPs' accountability and interactivity on its PW.Therefore, we can say that all Arab PWs still lag in deploying digital technologies for citizen engagement, as they do not provide the complete and necessary information to make their MPs accountable and the effective conduits to enhance their MPs' interactivity with citizens. Thus, we can conclude that the aim of building these websites is basically concerned with the web presence, in addition to the provision of some documents and bills.

This fact yields the first scenario proposed by (Coleman, 2006) regarding the consequences of digital interactivity for parliamentary democracy, which indicates that "parliaments remain much the same as they are now, utilizing the internet as a means of telling the public they exist, but resisting the interactive opportunities that could create spaces of common deliberation involving both politicians and citizens".

Depending on the "agency-theory", these findings reflect a situation of "hidden actions" which lead to an agency problem: the "moral hazard" problem. This problem, as stated before, arises when agents, once selected, have incentives and opportunity to take unobservable action that is contrary to the interests of the principal, and the principal cannot directly control the agent's action.

\section{DISCUSSION}

The result of this study regarding MPs' interactivity, which indicated that none of the Arab PWs have exceeded the (0.5) threshold is a confirmation of our previous study (Arrif, 2018), which was conducted on eight Arab countries and indicated the same result, although it was extended with more items to measure the interactivity of the Parliament as a whole.

What was remarkable through our two studies, is that most Arab PWs share social media links to their parliaments, but only Bahrain and Oman share social media links for their MPs. This phenomenon is widespread among the parliaments in different parts of the world. The Nigerian and South African PWs are such examples. The study of (Odeyemi and Abioro, 2019) indicated that most of the MPs have personal pages built into the Nigerian and South African PWs, but there is no record of any personal social media account.

In contrary to what is usual for most parliaments around the world, Arab PWs except UAE, Saudi, Bahrain, and Oman avoid providing MPs' e-mail addresses. For instance, (89\%) 39 out of 44 European parliaments have set up e-mail addresses for all elected members as (Coleman, 2006) stated, and in the case of Finnish parliament only (5.7\%) of MPs do not 
International Journal of Management Technology

Vol.7, No 1, pp. 1-19, January 2020

Published by ECRTD-UK

Print ISSN: ISSN 2055-0847(Print), Online ISSN: ISSN 2055-0855(Online)

provide an e-mail address as (Suomi, 2008) stated, noticing that these figures might be enhanced now.

As PWs of Bahrain and Oman has the best degree of interactivity on the Arab region, thus we can say that they are counterparts to the portal of the Brazilian Chamber of Deputies, which the study of (De Barros, Bernardes and Rehbein, 2016) stated that it was considered to be the one with the highest degree of interactivity with the public among the parliaments of South America.

Finally, and regarding MPs' accountability, the situation of Arab citizens is similar to the Ugandan. The study of (Humphreys and Weinstein, 2012) concluded that the Uganda's voting population lacks access to a well-developed media that might transmit information about the characteristics or activities of politicians.

\section{CONCLUSION}

One of the most serious consequences for the unavailability of MP's accountability and conduits of interactivity with the public is, people inability to sanction MP's when they shirk their duties or might hide conflicts of interests if they have any moonlighting activities. Thus, people continue to feel estranged and unheard, as (Coleman, 2006) stated. Voters expect that their elected representatives will be accessible and accountable to them. Mechanisms need to be in place so that citizens can hold their elected representatives to account (Jahan, 2014).

This study concludes with that the most appreciate recommendation for Arab PWs to enhance MPs accountability and interactivity, and foster democracy, is to develop MPs scorecards similar to those suggested by the study of (Humphreys and Weinstein, 2012). Each scorecard should not only contain what Humphreys and Weinstein stated regarding detailed information on MP's performance in plenary sessions of parliament, committee work and constituency service, but must be widened with: MP's personal information, biography, contact addresses, moonlighting activities and other related information. These scorecards might be developed by parliaments themselves and reported periodically on their websites, or by Partnering with a local non-governmental organization (NGO) and published on a separate platform linked to the official website of the parliament. The Tunisian platform ALMARSAD is such a successful example for what we propound here, which inspired other platforms to simulate it such as the Greek Vouliwatch.gr.

According to the agency-theory, this procedure forms ex post mechanisms control, which permits the principals to learn about agent's action after the fact, as (Strom, 2000; DE DIOS, 2014) stated. And should not be applied before changing the political culture, by confirming that legislators have the will and ability to be accountable and interact with the public, and that the latter also have the will and ability to monitor the performance of their MPs. 
International Journal of Management Technology

Vol.7, No 1, pp. 1-19, January 2020

Published by ECRTD-UK

Print ISSN: ISSN 2055-0847(Print), Online ISSN: ISSN 2055-0855(Online)

Also, we adopt the Inter-Parliamentary Union suggestion of collaborating with external (non-parliamentary) organizations to strengthen links with the public. There are now a host of mediating bodies that summarize and interpret parliamentary activity, broadcast parliamentary proceedings and rate the performance of individual MPs (Power, 2012).

\section{References}

Achen, C. H., \& Bartels, L. M. (2004). Blind retrospection: Electoral responses to drought, flu, and shark attacks. Presented at the Annual Meeting of the American Political Science Association, Boston, MA.

Aghion, P., \& Tirole, J. (1997). Formal and real authority in organizations. Journal of political economy, 105(1), 1-29.

Ahmed, M. A. (2008, June). Developing parliamentary web portals for citizens, MPs and related groups-Challenges and proposed solutions. In 2008 IEEE International Symposium on Technology and Society (pp. 1-7). IEEE.

Arrif, M. (2018). A Comparative Content Analysis of the Services of Arab Parliamentary Websites. Journal of Information Technology Management, 29(4), 49-63.

Asamoah, J. K. (2018). The concept of agency theory in electoral democracy. Journal of African Elections, 17(2), 66-82.

Bernardes, C. B., \& Bandeira, C. L. (2016). Information vs Engagement in parliamentary websites-a case study of Brazil and the UK. Revista de Sociologia e Política, 24(59), 91-107.

Berntzen, L., Healy, M., Hahamis, P., Dunville, D., and Esteves, J. (2006). Parliamentary web presence: A comparative review. Paper published in the Proceedings of the 2nd International Conference on e-Government (ICEG 2006), Pittsburgh, USA. Academic Conferences International, 12-13 October, pp. 17-25.

Borge Bravo, R., \& Esteve del Valle, M. (2017). Opinion leadership in parliamentary Twitter networks: A matter of layers of interaction?. Journal of Information Technology \& Politics, 14(3), 263-276.

Coleman, S. (2006, September). Parliamentary communication in an age of digital interactivity. In ASLIB proceedings (Vol. 58, No. 5, pp. 371-388). Emerald Group Publishing Limited.

De Barros, A. T., Bernardes, C. B., \& Rehbein, M. (2016). Brazilian Parliament and digital engagement. The Journal of Legislative Studies, 22(4), 540-558.

DE DIOS, M. S. (2014). Different comparative approaches in the study of parliaments. Paper prepared for the First Annual Conference of the ERASMUS Academic Network on Parliamentary Democracy in Europe (PADEMIA), Brussels 12-13 June.

Francoli, M. (2008). Parliaments Online: Modernizing and Engaging?. In Parliaments in the digital age: Forum discussion paper (Vol. 13, pp. 4-8).

Gailmard, S. (2012). Accountability and principal-agent models. Chapter prepared for the Oxford Handbook of Public Accountability. Oxford University Press.

Geys, B., \& Mause, K. (2012). Delegation, accountability and legislator moonlighting: Agency problems in Germany. German Politics, 21(3), 255-273. 
International Journal of Management Technology

Vol.7, No 1, pp. 1-19, January 2020

Published by ECRTD-UK

Print ISSN: ISSN 2055-0847(Print), Online ISSN: ISSN 2055-0855(Online)

Grant, R. W., \& Keohane, R. O. (2005). Accountability and abuses of power in world politics. American political science review, 99(1), 29-43.

Griffith, J. C. (2006). Beyond transparency: New standards for legislative information systems. Geneva, Switzerland: European Centre for Parliamentary Research and Documentation.

Griffith, J., \& Leston-Bandeira, C. (2012). How are parliaments using new media to engage with citizens?. The Journal of Legislative Studies, 18(3-4), 496-513.

Hamajoda, A. (2016). Informing and Interacting with Citizens: A Strategic Communication Review of the Websites of the ECOWAS Parliaments. The Electronic Journal of Information Systems in Developing Countries, 74(1), 1-13.

Healy, A., \& Malhotra, N. (2010). Random events, economic losses, and retrospective voting: Implications for democratic competence. Quarterly Journal of Political Science, 5(2), 193-208.

Humphreys, M., \& Weinstein, J. (2012). Policing politicians: citizen empowerment and political accountability in Uganda preliminary analysis. Columbia Universities. Unpublished manuscript.

Inter-Parliamentary Union. (2009). Guidelines for Parliamentary Websites. Geneva.

Jahan, R. (2015). The parliament of Bangladesh: representation and accountability. The Journal of Legislative Studies, 21(2), 250-269.

Joshi, D., \& Rosenfield, E. (2013). MP transparency, communication links and social media: A comparative assessment of 184 parliamentary websites. The Journal of Legislative Studies, 19(4), 526-545.

Karlsson, M. (2013). Representation as interactive communication: theoretical considerations and empirical findings. Information, Communication \& Society, 16(8), 1201-1222.

Kelso, A. (2007). Parliament and political disengagement: neither waving nor drowning. The Political Quarterly, 78(3), 364-373.

Kiewiet, D. R., \& McCubbins, M. D. (1991). The logic of delegation. University of Chicago Press.

Kingham, T. (2003). E-Parliaments: the use of information and communication technologies to improve parliamentary processes. Washington DC: World Bank Institute.

Lenz Gabriel, S. (2012). Follow the Leader?: How Voters Respond to Politicians' Policies and Performance, University of Chicago Press, Chicago.

Leston-Bandeira, C. (2009). Parliamentary functions portrayed on European parliaments' websites. Revista de Sociologia e Política, 17(34), 13-27.

Leston-Bandeira, C. (2012). Parliaments' endless pursuit of trust: Re-focusing on symbolic representation. The Journal of Legislative Studies, 18(3-4), 514-526.

Lupia, A., \& McCubbins, M. D. (2000). Representation or abdication? How citizens use institutions to help delegation succeed. European Journal of Political Research, 37(3), 291-307.

Lupia, A., McCubbins, M. D., \& Arthur, L. (1998). The democratic dilemma: Can citizens learn what they need to know?. Cambridge University Press. 
International Journal of Management Technology

Vol.7, No 1, pp. 1-19, January 2020

Published by ECRTD-UK

Print ISSN: ISSN 2055-0847(Print), Online ISSN: ISSN 2055-0855(Online)

Lupia, Arthur (2003). Delegation and its Perils. In Delegation and Accountability in Parliamentary Democracies, K. Strøm, W. C. Müller and T. Bergman (eds.) Oxford: Oxford University Press.

Manda, P. A., \& Hilika, A. R. (2016). Internet access and use in political discourse by the Members of Parliament in Tanzania. University of Dar es Salaam Library Journal, 11(2), 31-44.

Missingham, R. (2011). E-parliament: Opening the door. Government Information Quarterly, 28(3), 426-434.

Norton, P. (2007). Four models of political representation: British MPs and the use of ICT. The Journal of Legislative Studies, 13(3), 354-369.

Odeyemi, T. I., \& Abioro, T. (2019). Digital Technologies, Online Engagement and Parliament-Citizen Relations in Nigeria and South Africa. In Perspectives on the Legislature and the Prospects of Accountability in Nigeria and South Africa (pp. 217-232). Springer, Cham.

Oni, A. A., Oni, S., \& Ibietan, J. (2016). ICT and Democratic Parliament in Africa: State of the Matter. Journal of Governance and Development, 12(1), 71-85.

Parajuli, J. (2007). A Content Analysis of Selected Government Web Sites: A Case Study of Nepal. Electronic Journal of e-Government, 5(1), pp. 87-94.

Power, G. (2012). Global Parliamentary Report: The changing nature of parliamentary representation. Inter-Parliamentary Union.

Serra-Silva, S. (2016). How are Parliaments using Internet and ICT in the service of Democratic Representation? A proposal to measure e-engagement from a top-down perspective1. In Paper to the IPSA 24th World Congress of Political Science, Poznan, Poland, July 23-28, (pp. 23-28).

Setälä, M., \& Grönlund, K. (2006). Parliamentary websites: Theoretical and comparative perspectives. Information Polity, 11(2), 149-162.

Sobaci, Z. (2010). What the Turkish parliamentary web site offers to citizens in terms of e-participation: A content analysis. Information Polity, 15(3), 227-241.

Soultanian, V. S. G. (2013). To what extent can electronic parliament be applied in Jordan. European Scientific Journal, 9(1), 163-167.

Sprungk, C. (2010). Ever more or ever better scrutiny? Analyzing the conditions of effective national parliamentary involvement in EU affairs. European Integration online Papers (EIoP), 14.

Strøm, K. (2000). Delegation and accountability in parliamentary democracies. European journal of political research, 37(3), 261-290.

Suomi, R. (2008). Blogging as a Democracy Tool for Members of Parliament - Some Finnish Empirical Results. In proceedings of the 6th International Eastern European e|Gov Days, Prague, $23^{\text {rd }}-25^{\text {th }}$ April.

Trechsel, A. H., Kies, R., Mendez, F., \& Schmitter, P. (2003). Evaluation of the use of new technologies in order to facilitate democracy in Europe. Public report for the Scientific and Technological Option Assessment (STOA), European Parliament Directorate-General for Research. European Parliament. 
International Journal of Management Technology

Vol.7, No 1, pp. 1-19, January 2020

Published by ECRTD-UK

Print ISSN: ISSN 2055-0847(Print), Online ISSN: ISSN 2055-0855(Online)

Tyumre, M. G. (2012). E-Parliament to e-democracy: creating a model for effective management of public content (Doctoral dissertation, Stellenbosch: Stellenbosch University).

Walker, A. (2012). A People's Parliament?. Parliamentary Affairs, 65(1), 270-280.

Williamson, A., Korris, M., Fallon, F., AlLen, B., Wilkinson, C. A., Drake, A., \& Whitehead, S. (2011). Connecting citizens to parliament: how parliament can engage more effectively with hard to reach groups. London: Hansard Society.

Zaharudin, N., Bakar, A. N., Hashim, R., \& Rauf, A. (2014, December). An Empirical Analysis of System Factor as a Critical Determinant of Members of Parliament (MPs) Engagement in Information Communication Technology (ICT) in Malaysia. In Proceedings of International Conference on Contemporary Economic Issues 2014 (p. 151).

\section{AUTHOR BIOGRAPHY}

Majdi Soubhi Arrif is a lecturer (assistant professor) of Information and Decision Support Systems at the Faculty of Finance and Administrative Sciences, Al-Wataniya Private University, Hama, Syria. He is cofounder of The European Centre for Economic Studies of the Arab Orient (ECESAO). Holds $\mathrm{PhD}$ of Management Information Systems from Tishreen University, Faculty of Economics, Syria. He focused in his Master and Ph.D. on applying (MIS) in public administrations, and banks in Syria. He has published three articles that addressed Business Processes Reengineering, E-Government and EParliament. 